\title{
EFEKTIVITAS PUPUK ORGANIK FESES KUDA HASIL PEMBAKARAN TERHADAP PERTUMBUHAN TANAMAN CABAI MERAH KERITING (Capsicum annum L)
}

\author{
The Effectiveness Organic Fertilizer Of Combustion Result On Growth Of Red Chili Pepper In \\ Pataro Village, Herlang Distric Bulukumba Regency \\ ${ }^{1 *}$ Darmawan Risal, ${ }^{1}$ Nurul Mukhlishah \\ ${ }^{1}$ Fakultas Pertanian, Universitas Indonesia Timur \\ *Corresponding email: darmawanrisalrauf@yahoo.com
}

\begin{abstract}
Organic material derived from horse manure is very abundant and has the potential to be used as organic fertilizer with good nutrient content for plants. This study to utilize organic manure from combustion for growth and productivity of the red chili. In addition, this research was conducted to obtain the right composition of fertilizer doses to increase the growth and production of curly red chili. The method to use the Alfisol soil growing media at the site using polybag by treating different doses on each treatment. The number of treatments were given doses of $0 \mathrm{~g}$ (P0), $1 \mathrm{~g}$ (P1), $284 \mathrm{~g}$ (P2), $426 \mathrm{~g}$ (P3) and $568 \mathrm{~g}(\mathrm{P} 4)$ with replications each three times. Analysis metode for use macro nutrient content $(\mathrm{N}, \mathrm{P}, \mathrm{K})$ and data collection in the form of plant height, leaves, production and environmental factors. Data analysis used Duncan $\alpha 0.05$. The results of the analysis of the treatment effect on plant height were P4 (Media of soil with combustion horse fertilizer from $568 \mathrm{~g}$ ) treatment significantly different from other treatments. While other treatments did not show a significant difference in plant height. The effect of treatment on the number of leaves showed no real effect. In the growth and production of curly red chilies there are markedly significant differences. P4 is significantly different from P3, P2, P1 and $\mathrm{P} 0$. Whereas $\mathrm{P} 3$ is not significantly different from $\mathrm{P} 1$ as well as $\mathrm{P} 2$ which is significantly different from other treatments. $\mathrm{P} 4$ is a treatment with a large number of fruits with an average of 10.3 pieces. While treatment with a small number of fruits is $\mathrm{P} 0$ with an average of 2.3 fruits. Combustion horse
\end{abstract}

manure organic fertilizer is quite effective in increasing the growth and production of red chili. It can be assessed from the development of plant height and number of fruits on curly red chili plants. The dose of horse manure organic fertilizer which is good enough for curly red chili plants is $568 \mathrm{~g}$.

Keywords: fertility, growth, productivity

\section{PENDAHULUAN}

Biomassa yang dihasilkan oleh ternak kuda dalam bentuk feses cukup melimpah. Setiap ekor, ternak kuda dapat menghasilkan feses padat sebanyak $16,1 \mathrm{Kg}^{-1}$ Hari $^{-1}$. Selain feses padat, dapat juga menghasilkan feses cair sebanyak 3,63 $\mathrm{Kg}^{-1} \mathrm{Hari}^{-1}$ (Solihin, 2016). Potensi biomassa dari ternak kuda merupakan peluang yang sangat baik jika dimanfaatkan oleh petani untuk digunakan pada tanaman sebagai pupuk organik.

Feses padat kuda memiliki kandungan hara yang baik digunakan pada tanaman. Menurut (Solihin, 2016), feses kuda memiliki kandungan unsur hara yaitu $0,55 \% \mathrm{~N}, 0,30 \% \mathrm{P}, 0,40 \mathrm{Ca}$ dan $75 \%$ air. Feses cair (urine) kuda mengandung senyawa-senyawa aktif yang memungkinkan bakteri berkembang baik. Selain hara makro, feses kuda juga memiliki nilai karbon (C) yang tinggi dalam bentuk abu hasil pembakaran. Menurut (Rahmadi, 2016) abu dapat mengikat unsur hara yang tersedia di dalam pasir dan meningkatkan retensi air karena partikel abu bermuatan negatif sehingga molekul air mudah diikat. Menurut (Bungay, 1981) feses kuda 
merupakan bahan penghantar energi dengan kandungan energi $1 / 3$ dari batubara per unit massa dan $1 / 4$ energi batubara per unit volume jika dalam bentuk media briket. Adanya kandungan energi tersebut, sehingga feses kuda dikategorikan sebagai hot manure.

Pemanfaatan feses kuda sebagai pupuk organik pada tanaman masih belum terlalu diminati oleh sebagian petani. Petani masih mengalami beberapa kendala untuk menggunakannya secara langsung pada tanaman. Masalahnya adalah masih banyak terdapat serasah dan bahan organik pada feses kuda sehingga membutuhkan proses dekompisisi lanjutan di dalam tanah dalam waktu yang cukup lama untuk di serap oleh tanaman. Selain itu, jumlah biomassa yang dibutuhkan cukup banyak untuk memenuhi kebutuhan hara makro dan mikro pada tanaman karena kebutuhan input hara tidak sebanding dengan kandungan hara tersedia dalam tanah. Masalah tersebut membuat petani cenderung memilih pupuk kimia untuk digunakan pada tanamannya. Oleh karena itu, diperlukan model pengolahan lain untuk mempercepat proses penguraian serasah pada feses kuda dan meningkatkan kandungan unsur hara sehingga dapat dimanfaatkan langsung pada tanaman.

Pengolahan yang dilakukan secara baik diyakini mampu menjadikan feses kuda sebagai salah satu pupuk organik dengan kandungan hara yang tinggi dan biaya pembuatan yang murah. Caranya adalah dengan membuat pupuk organik feses kuda melalui proses pembakaran. Proses pembakaran dilakukan menggunakan bahan tambahan yaitu sabut kelapa untuk mempermudah pembakaran dan menambah kandungan hara, dimana output dari sebagian hasil pembakaran adalah abu. Penelitian (Basu et al, 2009) menjelaskan bahwa abu hasil pembakaran memiliki kandungan unsur makro dan mikro yang tinggi seperti ( $\mathrm{K}, \mathrm{Na}, \mathrm{Zn}, \mathrm{Ca}, \mathrm{Mg}$ dan $\mathrm{Fe}$ ) yang dapat meningkatkan hasil panen tanaman pertanian. Hasil penelitian (Risnah et al, 2013) menjelaskan bahwa karakteristik yang dimiliki abu sabut kelapa memiliki kandungan $\mathrm{K}$ total yang tinggi sekitar 21,875 serta nilai KTK yang baik yaitu 13,29 me100 $\mathrm{g}^{-1}$. Penelitan (Tateno et al, 2019) menjelaskan bahwa kandungan $\mathrm{C} / \mathrm{N}$ pada abu akan semakin bertambah dalam kurung waktu yang semakin lama dan dalam kondisi suhu yang berbeda.

Menurut (Boyle, 2001), proses pembakaran merupakan dekomposisi kimia yang merubah biomassa menjadi energi kimia dan menjadikan sebagian bahan baku sebagai bioarang. Pembakaran dilakukan dengan proses pirolisis yaitu tanpa oksigen. Porses tanpa oksigen tidak menimbulkan dampak yang sangat besar terhadap pencemaran lingkungan. Proses ini juga mempermudah mengentrol proses pembentukan struktur dan tekstur pada biomassa feses kuda. Sehingga, hasil yang diperoleh tidak sepenuhnya merupakan abu.

Selanjutnya, untuk mengetahui efektivitas pupuk organik yang dihasilkan, maka dilakukan penelitian pupuk organik feses kuda hasil pembakaran diberikan pada tanaman cabai merah keriting (Capsicum annum L) sebagai input untuk melihat pengaruhnya terhadap pertumbuhan.

\section{METODOLOGI}

Lokasi penelitian terletak di Dusun Macinna Desa Pataro Kecamatan Herlang Kabupaten Bulukumba. Penelitian dilaksanakan di kebun milik salah satu warga dengan membuat green house sederhana di dalamnya. Metode penelitian dilakukan dengan beberapa tahapan. Tahapan pertama adalah bibit tanaman cabai merah keriting varietas Castillo disemai pada media semai. Sebelum disemai, benih direndam dalam air hangat $\left(50^{\circ} \mathrm{C}\right)$ selama tiga jam, untuk mempercepat perkecambahan dan menghilangkan hama/penyakit yang terbawa benih. Media yang digunakan adalah campuran sekam, tanah halus dan pupuk organik dengan perbandingan $(1: 1: 1)$. Tahapan kedua adalah pembakaran feses kuda. Pembakaran dilakukan dengan mengontrol suhu dengan lama pembakaran 
selama 30 menit. Bahan yang disiapkan adalah alat dan bahan pembakaran seperti drum besi, tempurung kelapa dan bongkahan kayu kering. Tahapan ketiga adalah persiapan pupuk dan media tanam. Pupuk organik feses kuda hasil pembakaran yang sudah matang dengan karakteristik beremah dan tidak berbau ditimbang. Dosis pupuk yang digunakan adalah $0 \mathrm{~g}, 1 \mathrm{~g}, 284$ g, 426 g dan 568 g (Paridah, 2005) dengan uraian sebagai berikut P0: Media tanah tanpa pupuk feses kuda, P1: Media tanah dengan pupuk feses kuda hasil pembakaran sebanyak 1 g, P2: Media tanah dengan pupuk feses kuda hasil pembakaran sebanyak 284 g, P3: Media tanah dengan pupuk feses kuda hasil pembakaran sebanyak 426 g, P4: Media tanah dengan pupuk feses kuda hasil pembakaran sebanyak 568 g. Sedangkan media tanam yang digunakan adalah top soil alfisol yang dimuat dalam polybag ukuran $50 \mathrm{~cm}$ x 40 $\mathrm{cm}$ dengan berat masing-masing $5 \mathrm{~kg}$. Tahapan ke empat adalah penanaman dan pemeliharaan. Parameter yang diamati adalah tinggi tanaman, jumlah daun, produksi (jumlah dan berat buah).

Setiap perlakuan diulang masingmasing tiga kali. Analisis laboratorium yang dilakukan adalah hara makro (N,P,K) dan data primer seperti tinggi tanaman, jumlah daun, produksi cabai dan faktor lingkungan. Analisis data menggunakan analisis SPSS dengan uji Duncan $\alpha 0,05$.

\section{HASIL DAN PEMBAHASAN}

\section{Efektivitas pupuk organik feses kuda hasil pembakaran terhadap pertumbuhan tanaman cabai merah keriting}

Hasil pertanaman cabai merah keriting dengan menggunakan tinggi tanaman sebagai parameter pengamatan dijelaskan bersama jumlah daun dan buah. Hasil penelitian ini memberikan gambaran mengenai pengaruh input pupuk organik feses kuda hasil pembakaran dengan beberapa jenis takaran atau dosis yang diberikan. Proses pertanaman dan pengamatan hanya dilakukan selama 75 hari setelah tanam. Berikut disajikan hasil analisis dan uji statistik pada tabel 1 .

Tabel 1. Pertumbuhan dan hasil tanaman cabai merah keriting dari berbagai dosis pupuk feses kuda hasil pembakaran

\begin{tabular}{|c|c|c|c|c|c|c|}
\hline \multirow{2}{*}{$\begin{array}{l}\text { Para } \\
\text { meter }\end{array}$} & \multirow{2}{*}{ HST } & \multicolumn{5}{|c|}{$\begin{array}{c}\text { Dosis pupuk organik feses kuda hasil } \\
\text { pembakaran }\end{array}$} \\
\hline & & P0 & P1 & P2 & P3 & P4 \\
\hline \multirow{5}{*}{$\begin{array}{c}\text { Tinggi } \\
\text { tanaman } \\
(\mathrm{cm})\end{array}$} & $\begin{array}{c}15 \\
\text { HST }\end{array}$ & 7,32 & 8,34 & 8,75 & 8,93 & 9,61 \\
\hline & $\begin{array}{c}30 \\
\text { HST }\end{array}$ & 15,43 & 15,14 & 13,12 & 15,34 & 18,39 \\
\hline & $\begin{array}{c}45 \\
\text { HST }\end{array}$ & 19,21 & 21,55 & 20,11 & 20,36 & 30,14 \\
\hline & $\begin{array}{c}60 \\
\text { HST }\end{array}$ & 21,55 & 24,40 & 27,14 & 24,45 & 35,33 \\
\hline & $\begin{array}{c}75 \\
\text { HST }\end{array}$ & $23,22 a$ & $28,11 \mathrm{a}$ & $29,22 \mathrm{a}$ & $26,33 a$ & $41,89 b$ \\
\hline \multirow{5}{*}{$\begin{array}{c}\text { Jumlah } \\
\text { daun } \\
\text { (helai) }\end{array}$} & $\begin{array}{c}15 \\
\text { HST }\end{array}$ & 6,02 & 6,02 & 5,12 & 5,35 & 6,55 \\
\hline & $\begin{array}{c}30 \\
\text { HST }\end{array}$ & 6,16 & 6,16 & 6,18 & 7,56 & 8,45 \\
\hline & $\begin{array}{c}45 \\
\text { HST }\end{array}$ & 7,21 & 7,21 & 6,18 & 8,23 & 9,55 \\
\hline & $\begin{array}{c}60 \\
\text { HST }\end{array}$ & 9,23 & 9,23 & 7,21 & 9,55 & 10,78 \\
\hline & $\begin{array}{c}75 \\
\text { HST }\end{array}$ & $10.56 \mathrm{a}$ & $10,56 a$ & $8,44 a$ & 9,78a & $11,11 \mathrm{a}$ \\
\hline $\begin{array}{c}\text { Panjang } \\
\text { cabai } \\
\text { per buah } \\
(\mathrm{cm})\end{array}$ & $\begin{array}{c}75 \\
\text { HST }\end{array}$ & $15,32 a$ & $15,46 a$ & $15,3 a$ & $15,47 \mathrm{a}$ & $15,7 \mathbf{a}$ \\
\hline $\begin{array}{c}\text { Jumlah } \\
\text { buah } \\
\text { per } \\
\text { Tanaman }\end{array}$ & $\begin{array}{c}75 \\
\text { HST }\end{array}$ & $2 a$ & $3 \mathbf{b}$ & $4 c$ & $3 b$ & $10 d$ \\
\hline $\begin{array}{c}\text { Berat per } \\
\text { buah } \\
\text { (g) }\end{array}$ & $\begin{array}{c}75 \\
\text { HST }\end{array}$ & $10 a$ & $10 \mathrm{a}$ & $10 \mathrm{a}$ & $10 \mathrm{a}$ & $10 \mathrm{a}$ \\
\hline
\end{tabular}

Sumber: Hasil analisis statistik, diolah 2018.

Keterangan:

$$
\begin{aligned}
& \text { Angka angka yang masih diikuti huruf yang sama (a,b,c) } \\
& \text { menunjukkan tidak berbeda nyata. Uji Duncan } \alpha=0,05 \text {. } \\
& \text { P0: Media tanah tanpa pupuk feses kuda. } \\
& \text { P1: Media tanah dengan pupuk feses kuda hasil } \\
& \text { pembakaran sebanyak } 1 \mathrm{~g} \text {; } \\
& \text { P2: Media tanah dengan pupuk feses kuda hasil } \\
& \text { pembakaran sebanyak } 284 \mathrm{~g} \text {; } \\
& \text { P3: Media tanah dengan pupuk feses kuda hasil } \\
& \text { pembakaran sebanyak } 426 \mathrm{~g} \text {; } \\
& \text { P4: Media tanah dengan pupuk feses kuda hasil } \\
& \text { pembakaran sebanyak } 568 \text {. }
\end{aligned}
$$

Input pupuk organik feses kuda hasil pembakaran pada tanaman cabai merah keriting yang memperoleh hasil terbaik berada pada dosis $568 \mathrm{~g}$ per tanaman. Pada analisis tinggi tanaman, perlakuan P4 berbeda nyata dengan perlakuan lainnya. Pertumbuhan tinggi tanaman pada P4 cukup 
baik karena jumlah kandunganhara yang lebih tinggi dibandingkan dengan perlakuan lainnya. Volume pupuk organik yang diberikan akan berbanding lurus dengan kandungan hara yang tersedia di dalamnya, sehingga tanaman akan dapat menyerap hara dalam jumlah yang banyak pula. Kandungan hara dalam pupuk yang bercampur dengan abu akan meningkatkan kualitas tanah dan kemampuannya mengikat air. Menurut (Rahmadi, 2016) menjelaskan bahwa abu dapat mengikat unsur hara yang tersedia di dalam pasir dan meningkatkan retensi air karena partikel abu bermuatan negatif segingga molekul air mudah diikat.

Pemberian pupuk organik dilakukan secara bertahap sebanyak tiga kali yaitu 0 HST atau pada saat pengisian polibag dengan tanah, 30 HST dan 60 HST. Pemberian pupuk organik melalui pembenaman dilakukan pada awal pertanaman. Tujuannya adalah untuk menjaga ketersediaan hara pada tanah dan sebagai sumber makanan pada tanaman cabai. Perlakuan ini sejalan dengan (Paridah, 2005) yaitu proses penguraian yang cepat pada feses kuda dilakukan pada fase awal yaitu dengan melakukan pembenaman selama satu minggu sebelum masa tanam. Perlakuan bertahap dilakukan untuk mencegah hilangnya unsur hara di dalam pupuk melalui proses pencucian maupun penguapan.

Berdasarkan hasil pengamatan, jumlah dosis pupuk organik feses kuda dalam jumlah lebih, tidak memberikan efek negatif terhadap pertumbuhan cabai. Selain itu, jumlah dosis yang cukup tinggi memang sangat perlu dilakukan karena tanah yang digunakan merupakan tanah dengan nilai kesuburan cukup rendah. (Hardjowigeno, 2003) mengemukakan bahwa kandungan unsur hara dalam pupuk organik per setiap takarannya memang tidak terlalu tinggi. Namun dengan dilakukannya proses pembakaran maka nilai kandungan hara makro dan mikro pada feses kuda semakin bertambah. Berdasarkan hasil analisis laboratorium, persentasi kandungan hara makro $(\mathrm{N}, \mathrm{P}, \mathrm{K})$ pada pupuk organik feses kuda hasil pembakaran menunjukkan nilai yang sangat baik dimana $\mathrm{N}$ adalah $0,58 \%$, $\mathrm{P} 2 \mathrm{O} 5$ adalah $3,85 \%$ dan $\mathrm{K} 2 \mathrm{O}$ adalah $4,52 \%$. Nilai hara makro ini cukup tinggi dibandingkan dengan nilai rata-rata persentasi kandungan pupuk organik feses kuda pada biasanya dimana $\mathrm{H}_{2} \mathrm{O}$ adalah $78 \%$, nilai $\mathrm{N} 0,70 \%$, nilai $\mathrm{P}_{2} \mathrm{O}_{5} 0,25 \%$ dan $\mathrm{K}_{2} \mathrm{O}$ adalah $0,55 \%$ (Sarief, 1986).

Persentasi dari kandungan hara makro yang dimiliki pupuk organik feses kuda hasil pembakaran memberikan kontribusi yang cukup untuk mempengaruhi pertumbuhan tanaman cabai khususnya pada perkembangan tinggi tanaman. Penelitian ini sejalan dengan hasil penelitian (Basu et al, 2009) yang menjelaskan bahwa abu hasil pembakaran memiliki kandungan unsur makro dan mikro yang tinggi seperti (K, Na, $\mathrm{Zn}, \mathrm{Ca}, \mathrm{Mg}$ dan $\mathrm{Fe}$ ). Menurut (Kiswondo, 2011) Kandungan hara $\mathrm{K}$ dan $\mathrm{N}$ akan dapat meningkatkan pertumbuhan dan hasil tanaman.

\section{Efektivitas pupuk organik feses kuda hasil pembakaran terhadap jumlah daun}

Hasil analisis menunjukkan bahwa pertumbuhan jumlah daun pada tanaman cabai merah keriting tidak menunjukkan perbedaan yang nyata pada setiap perlakuan. Pertumbuhan jumlah daun pada tanaman cabai mengalami kendala pada umur 20 HST. Hampir semua tanaman cabai, daunnya dimakan oleh serangga. Sehingga untuk menghindari kerusakan lanjutan dilakukan dengan menggunakan pestisida nabati yang terbuat dari bahan alami. Perlakuan tersebut dilakukan sebanyak dua hari pada waktu pagi dan petang. Faktor lain yang menjadi penyebab banyaknya serangga adalah kelembaban areal pertanaman akibat curah hujan yang tinggi dan gulma yang ada pada sekitaran polibag. Serangga akan mudah tumbuh dan berkembang pada wilayah dengan suhu dan kelembaban rendah. Hal ini didasarkan pada syarat tumbuh tanaman cabai dimana suhu dan kelembaban yang terlalu tinggi dan sangat rendah akan mengakibatkan buah dan daun 
yang dihasilkan kurang baik. Suhu yang terlalu dingin menyebabkan pertumbuhan tanaman terhambat, pembentukan bunga kurang sempurna, dan pemasakan buah lebih lama.

\section{Efektivitas pupuk organik feses kuda hasil pembakaran terhadap produksi buah (panjang, jumlah dan berat)}

Berdasarkan hasil pengamatan dan analisis pada pertumbuhan dan produksi buah cabai merah keriting meunjukkan bahwa parameter jumlah buah yang memiliki perbedaan nyata. P4 berbeda nyata dengan dengan P3, P2, P1 dan P0. Sedangkan P3 tidak berbeda nyata dengan $\mathrm{P} 1$ begitupun $\mathrm{P} 2$ yang berbeda nyata dengan perlakuan lainnya. P4 merupakan perlakuan dengan jumlah buah yang banyak dengan rata rata 10,3 buah. Sedangkan perlakuan dengan jumlah buah yang sedikit adalah P0 dengan rata-rata 2,3 buah. Peningkatan jumlah buah pada $\mathrm{P} 4$ sejalan dengan jumlah input pupuk organik feses kuda hasil pembakaran yang cukup tinggi yaitu $568 \mathrm{~g}$.

Peningkatan jumlah buah pada setiap pertanaman juga ditengarai oleh adanya input abu dari sisa hasil pembakaran yang bercampur dengan pupuk organik. Abu merupakan biomassa tambahan dalam pupuk organik yang memiliki banyak fungsi. Menurut (Lehman, 2007), tekstur yang lembut dari abu menyebabkan abu lebih mudah mengisi pori-pori pada pasir, sehingga dapat membantu memperbaiki struktur media tanam dan mampu mengikat unsur hara yang tersedia di dalam media tanam, khususnya pasir. Hasil penelitian (Risnah et al, 2013) menjelaskan bahwa karakteristik yang dimiliki abu sabut kelapa memiliki kandungan $\mathrm{K}$ total yang tinggi sekitar 21,875 serta nilai KTK yang baik yaitu $13,29 \mathrm{me}^{100 \mathrm{~g}^{-1}}$. Adanya peran abu dalam pupuk organik feses kuda hasil pembakaran memberikan nilai tambah dalam meningkatkan produksi cabai khususnya pada pertambahan buahnya.

Pengamatan dan analisis berat dan panjang buah menunjukkan hasil yang tidak bereda nyata pada setiap perlakuan. Hal ini disebabkan karena varietas yang digunakan memiliki keunggulan yang sama dengan panjang dan berat per buah hampir sama. Sedangkan produksi buah ditentukan berdasarkan jumlah buah cabai dari setiap pohon tanaman cabai

\section{KESIMPULAN}

Berdasarkan hasil pengamatan dan analisis penelitian efektivitas pupuk organik feses kuda hasil pembakaran terhadap pertumbuhan cabai merah keriting, maka dapat ditarik kesimpulan bahwa pupuk organik feses kuda hasil pembakaran cukup efektif dalam meningkatkan produksi. Hal tersebut dapat dinilai dari perkembangan tinggi tanaman dan jumlah buah pada tanaman cabai merah keriting. Hasil tersebut juga didasarkan pada analisis statistik dimana perlakuan P4 merupakan perlakuan yang terbaik dan berbeda nyata dengan perlakuan lainnya. Dosis pupuk organik feses kuda hasil pembakaran yang cukup baik untuk tanaman cabai merah keriting adalah 568 g. Pengaruh yang cukup nyata adalah dalam tinggi tanaman dan jumlah buah.

\section{DAFTAR PUSTAKA}

Basu, M. Pande M, Bhadoria, P.B.S, Mahapatra, S.C. 2009. Potential Flyash Utilization in Agriculture: A Global Review. Progrress in Natural Science 19; 1173-1186.

Bungay, H.R. 1981. Energy: The Biomass Options, John Wiley\&Sons, New York.

Hardjowigeno, Sarwono. 2003. Ilmu Tanah. Penerbit Akademika Pressindo: Jakarta.

Kiswondo, S. 2011. Penggunaan Abu Sekam dan Pupuk ZA Terhadap Pertumbuhan dan Hasil Tanaman 
Tomat (Lycopersicum esculentum Mill.) EMBRYO. 8 No 1. Fakultas Pertanian Universitas Moch. Sroedji. Jember.

Las, I. 2010. Arah dan Strategi. Pengembangan Pupuk Majemuk NPK dan Pupuk Organik, Seminar Nasional Peranan Pupuk NPK dan Organik dalam Meningkatkan Produksi dan Swasembada Beras Berkelanjutan. Badan Penelitian dan Pengembangan Pertanian, Kementerian Pertanian. Jakarta.

Lehman, J. 2007. A Handful of Carbon. Natur. Nature Publishing Group. Vol. 477.

Paridah L. 2005. Pengaruh Pemberian Pupuk Feses Kuda Terhadap Pertumbuhan Jahe Emprit (Zingiber officinale var. Rubrum). Skripsi. Fakultas Matematika dan Ilmu Pengetahuan Alam Universitas Diponegoro. Semarang.

Rahmadi, I,A, Handayani, T, T. Lande, L, M. 2016. Pengaruh Abu dan Proporsi Pasir-Kompos di Dalam Media Pada Pertumbuhan Tanaman Sorgum (Sorghum bicolor L). Vol 16 (2); 101-108.

Solihin A. 2016. Kandungan Unsur Hara Pupuk Kandang dari Berbagai Jenis Ternak. Teknologi Pertanian. PADRANG Home.

Susana B. 2009. Peningkatan Nilai Kalor Biomassa Feses Kuda dengan Metode Densifikasi dan Thermolisis. Jurnal Teknik Mesin, Universitas
Mataram. Mataram. Vol. 11 No. 2. 103-107.

Tateno R, Tatsumi, C. Nakayama M, Takahashi, K. Kerfani, D. Adams, J. 2019. Temperature effects on the first three years of soil ecosystem developmenton volcanic ash. Elsevier. Catena 172. 1-10. 